\title{
Üniversite Öğrencilerinde Menstrual Semptom Yaşama Durumu ve Yaşam Kalitesine Etkisi
}

\author{
Yeşim Aksoy Derya $\odot$, Çiğdem Erdemoğlu@ $\odot$, Zeliha Özşahin $\odot$
}

İnönü Üniversitesi, Ebelik Anabilim Dalı, Malatya, Türkiye

Yeşim Aksoy Derya, Dr. Öğr. Üyesi Çiğdem Erdemoğlu, Arş.Gör. Zeliha Özşahin, Arş.Gör.

Illetişim:

Dr. Öğr. Üyesi Yeşim Aksoy Derya İnönü Üniversitesi, Ebelik Anabilim Dalı, Malatya, Türkiye

Tel: +904223773000

E-Posta:yesim.aksoy@inonu.edu.tr

Gönderilme Tarihi : 03 Ağustos 2017

Revizyon Tarihi : 27 Ağustos 2017

Kabul Tarihi : : 06 Eylül 2017
ÖZET

Amaç: Bu araştırmanın amacı, üniversite öğrencilerinde menstrual semptom yaşama durumu ve yaşam kalitesine etkisini belirlemektir.

Çalışma planı: Kesitsel nitelikte planlanan bu araşıırma Nisan-Mayıs 2017 tarihleri arasında bir kamu üniversitesinde yürütülmüştür. Örneklem büyüklüğ̈̈; \%99.9 güven aralığı, 0.05 yanılgı düzeyi ve $\% 80$ evreni temsil etme yeteneği ile 1019 kız öğrenci olarak belirlenmiştir. Veriler, "Kişisel Tanıtım Formu”, "Menstruasyon Semptom Ölı̧eği" ve "Yaşam Kalitesi Ölçeği" aracilığı ile elde edilmiştir. İstatistiksel değerlendirmede; sayı, yüzde, ortalama, standart sapma ve pearson korelasyon analizi kullanıımıştır.

Bulgular: Yaş ortalaması 20.82 \pm 1.67 olan öğrencilerin \%30'u birinci sınıf öğrencisi olup, \%84.4'ü gelirinin giderine eşit olduğunu belirtmiştir. Menarş yaş ortalaması 13.50 \pm 1.55 olan öğrencilerin, \%70.2'si menstruasyonunun düzenli olduğunu, \%45.2'si ise ailesinden en az birinin (anne/kız kardeş vb) menstrual yakınmaları yaşadığını belirtmiştir. Araştırmada menstrual semptom ölçeği toplam puan ortalaması $69.36 \pm 17.59$ 'dir. Öğrencilerin menstrual semptom ölçeği "negatif etkiler/somatik yakınmalar" alt boyutu puan ortalamasının $40.45 \pm 10.63$, "menstrual ağı belirtileri" alt boyutu puan ortalamasının $21.22 \pm 6.07$ ve "baş etme yöntemleri" alt boyutu puan ortalamasının $7.67 \pm 4.08$ olduğu belirlenmişstir. SF- 12 yaşam kalitesi "fiziksel bileşen özet skoru" ve "mental bileșen özet skoru" ile menstrual semptom ölçeği tüm alt boyut ve toplam puan ortalamaları arasında negatif yönde anlamlı bir ilişki olduğu ve menstrual sendrom şiddeti arttıkça fiziksel ve mental yaşam kalitesinin azaldığı saptanmıştır $(\mathbf{p}<0.001)$.

Sonuç: Öğrencilerde menstrual semptom yaşama sıkığının yaygın olduğu ve menstrual sendrom şiddeti arttıkça yaşam kalitesinin azaldığı belirlenmiş̧tir.

Anahtar sözcükler: Üniversite öğrencileri, menstrual semptom, yaşam kalitesi

\section{THE STATUS OF HAVING THE MENSTRUAL SYMPTOM IN UNIVERSITY STUDENTS AND ITS EFFECT ON QUALITY OF LIFE}

\section{ABSTRACT}

Aim: The aim of this study was to determine the status of university students to have menstrual symptom and its effect on quality of life.

Materials and Methods: This study was conducted in a cross-sectional design in a public university between April and May 2017. The sample size was determined as 1019 female students with a confidence interval of $99.9 \%$, significance level of 0.05 , and an ability of representing the population of $80 \%$. The data were collected by using "Personal Information Form", "Menstrual Symptom Scale", and "Life Quality Index". Numbers, percentages, mean, standard deviation, and pearson's correlation analysis were used for the statistical evaluation.

Results: $30 \%$ of the students with an average age of $20.82 \pm 1.67$ were in the first-year and $84.4 \%$ stated to have an income equals to the expenses. $70.2 \%$ of the students had a mean menarche age of $13.50 \pm 1.55$ indicating that their menstruation was regular and $45.2 \%$ stated that at least one person in their families (mother/sister, etc.) had menstrual complaints. The total mean score of menstrual symptom scale was $69.36 \pm 17.59$ in the study. It was determined that the menstrual symptom subscales were as follows, the "negative effects/somatic complaints" subscale mean score of the students was $40.45 \pm 10.63$, the mean score of "menstrual pain symptoms" subscale was $21.22 \pm 6.07$, and the mean score of "the coping methods" subscale was $7.67 \pm 4.08$. There was a negative significant correlation between SF-12 life quality "physical component summary score", "mental component summary score", all menstrual symptom scales' subscales and the total mean scores. It was found that as the severity of menstrual symptom increased, physical and mental quality of life decreased $(p<0.001)$.

Conclusion: It was determined that the prevalence of menstrual symptom was common among students and as the severity of menstrual syndrome increased, quality of life decreased.

Keywords: University students, menstrual symptom, quality of life 
M enstruasyon, menarşla birlikte başlayıp doğurganlık çağı boyunca aylık periyodlar şeklinde devam eden ve kadının fertilite yeteneğini gösteren normal fizyolojik bir süreçtir. Kadın hayatının yaklaşık yarısı menstruasyon süreci ve bu sürece yönelik fiziksel, davranışsal ve emosyonel değişikliklerin eşlik ettiği birtakım semptomlarla geçmektedir (1-3). Yapılan çalışmalarda yaklaşık her iki kadından birinde menstrual semptomların görüldüğü saptanmıştır. (4-6). Ayrıca kadınları üretkenlik çağı boyunca etkileyen bu semptomların en yaygın kadın sağlığı sorunları arasında yer aldığı bildirilmektedir (6-8).

Menstrual semptom prevalansı yüksek olmasına rağmen etiyolojisi henüz tam olarak bilinmemektedir. Ancak hormonal değişimler, nörotransmitterler, prostaglandinler, diyet, ilaçlar ve yaşam tarzı gibi faktörlerin menstrual semptomlar üzerinde etkili olduğu belirtilmektedir $(8,9)$. Menstruasyona bağlı bu semptomlar genel olarak premenstrual sendrom (PMS) ve dismenore olmak üzere iki grup altında sınıflandırımaktadır (10). Menstrual siklusun luteal fazında ortaya çıkan fiziksel, ruhsal sıkıntı ve/veya kadının sosyal ilişkilerini, normal aktivitesini bozacak derecede önemli davranış değişiklikleri Premenstrual Sendrom (PMS) olarak tanımlanmaktadır (11). Literatürde, kadınların yaklaşık \%80'inde hafif \%20-50'sinde orta, \%5'inde ise ciddi PMS semptomları yaşandığı bildirilmektedir (8). PMS'de menstruasyondan altı gün önce başlayan semptomlar menstruasyon kanamasının başlamasından iki gün önce ciddiyetini en üst seviyeye çıkarır. Benzer şikâyetler her siklusta görülmektedir $(3,12)$. Yaklaşık 200 semptomun bu sendromda görülebileceği bildirilmiştir $(1,3)$. Bu semptomlar; karın ve memelerde şişlik, hassasiyet, baş dönmesi, kilo alma, çarpıntı, bulantı, terleme gibi fiziksel semptomlar ve huzursuzluk, üzüntü hali, gerginlik, öfke, kendini küçük görme, agresyon gibi psikolojik semptomlardan oluşmaktadır $(1,13)$. Qiao ve arkadaşlarının yapmış oldukları çalışmada kadınlardaki en yaygın PMS semptomların; sinirlilik (\%91.21), meme hassasiyeti (\%77.62), depresyon (\%68.31), abdominal şişkinlik (\%63.70) ve öfke patlaması (\%9.62) olduğu saptanmıştır (14). Semptomlar intihara kadar götürücü ve başkalarına karşı şiddet hareketlerine sebep olacak kadar önemli olabilir $(1,13)$. Dünyadaki 40 milyon kadın bu semptomları yaşamakta ve 5 milyondan fazlası bu semptomların neden olduğu zihinsel ve davranışsal değişiklikler için tıbbi tedaviye intiyaç duymaktadır (12). Dismenore ise, kadınların menstruasyon ile birlikte ağrı duymalarıdır (15). Patel ve arkadaşlarının 2262 kadın üzerinde yapmış oldukları çalışmada katılımcıların yarısından fazlasının dismenore yaşadığı tespit edilmiştir (16). Dismenore, kadınların fiziksel aktivitelerinde ve sosyal rollerinde değişikliklere sebep olarak yaşam kalitesini düşürmektedir. Özellikle adölesan ve genç kadınların \%15'inde dismenoreye bağlı olarak okul devamsızlıklarında artma, ders başarısında veya üretkenlikte azalma gibi olumsuz etkilerin görüldüğü belirtilmektedir (10).

Menstrual dönemdeki bu semptomların, kadınların ve genç kızların sosyal ve aile ilişkilerini, fiziksel aktivitelerini, duygusal iyilik halini, çalışma hayatını ve yaşam kalitesini olumsuz yönde etkilediği bildirilmektedir $(5,9,10,17)$. Yapılan çalışmalarda, yaşam kalitesini etkileyecek düzeyde şiddetli menstrual semptom belirtileri yaşayan ve medikal tedaviyi gerektirenlerin oranı \%5-15 arasında olduğu saptanmıştır $(3,14,16)$. Ayrıca, menstrual semptomlar eğitim hayatını aksatmakta ve sosyal yaşamı olumsuz etkilemektedir (4,18-21). Oskay ve arkadaşları yapmış oldukları araştırmada kız öğrencilerin \%57.4'ünün menstruasyonda ağrının günlük yaşam aktivitelerini etkilediği, bundan dolayı \%33.5'inin sokağa çıkamadığı, \%31.9'unun ise okula işe gidemediğini saptamıştır (4).

Menstrual semptomlar kadınların özellikle genç kızların hayatını önemli ölçüde etkileyen ciddi bir sağlık sorunudur (18). Bu durum kız öğrencilerin kendine olan güvenini, toplumsal ilişkilerini ve derslere devamını olumsuz etkileyerek kız öğrencilerin yaşam kalitesini azaltmaktadır (2). Literatür incelendiğinde yapılan çalışmaların sadece PMS'ye ya da dismenoreye odaklandığı görülmektedir $(2,6,16,21)$. Bu araştırmada, premenstural sendromun neden olduğu negatif etkiler/somatik yakınmalar, menstrual ağrı belirtileri ve menstural semptomlarla baş etme yöntemleri aynı örneklem grubunda bir arada değerlendirilmiş ve yaşam kalitesine olan etkisi incelenmiştir.

\section{Gereç ve yöntem}

Kesitsel olarak planlanan bu araştırma Nisan-Mayıs 2017 tarihleri arasında İnönü Üniversitesi Merkez Kampüsünde yürütülmüştür. Araştırmanın evrenini, İnönü Üniversitesi merkez kampüsünde yer alan ve 2016-2017 EğitimÖğretim Bahar Yarıyılında farklı bölümlerde lisans öğrenimi gören 17129 kız öğrenci oluşturmuştur. Örneklem büyüklüğü; \%99.9 güven aralığı, 0.05 yanılgı düzeyi ve $\% 80$ evreni temsil etme yeteneği ile 1019 kız öğrenci olarak hesaplanmıştır. İnönü Üniversitesi Eğitim Fakültesi 2899, FenEdebiyat Fakültesi 2450, İktisadi ve İdari Bilimler Fakültesi 2342, İlahiyat Fakültesi 1170, Mühendislik Fakültesi 1000, Sağlık Bilimleri Fakültesi 398, Tıp Fakültesi 723, Eczacılık Fakültesi 232, Diş Hekimliği Fakültesi 203, Güzel Sanatlar ve Tasarım Fakültesi 350, Hukuk Fakültesi 359, İletişim Fakültesi 256, Beden Eğitimi ve Spor Yüksekokulu 271, Devlet konservatuarı 56 kız öğrenci kayıtlı bulunmaktadır. 
Fakülte veyüksekokullardan alınacaköğrenci sayısı fakültelerin evrendeki ağırlıkları ile orantılandırılarak belirlenmiş ve tabakalı örnekleme yöntemi ile seçilmiştir. Araştırmaya katılmayı kabul eden öğrenciler ilgili evrenden olasııısız rastlantısal örnekleme yöntemi ile seçilmiştir.

\section{Veri toplama araçları}

Veriler, "Kişisel Tanıtım Formu", "Mestruasyon Semptom Ölçeği" ve "Yaşam Kalitesi Ölçeği (SF -12)" kullanılarak elde edilmiştir.

\section{Kişisel tanıtım formu}

Öğrencilerin sosyodemografik özellikleri ile bazı menstrual özelliklerini belirlemek amacıyla araştırmacı tarafından oluşturulan bu form 8 sorudan (yaş, fakülte, sınıf, ekonomik durum, aile tipi, menarş yaşı, menstruasyon düzeni, ailede menstrul semptom varlığı) oluşmaktadır.

\section{Menstruasyon semptom ölçeği}

Menstruasyon Semptom Ölçeği (MSÖ), 1975'de Chesney ve Tasto tarafından menstruasyon ağrısı ve semptomlarını değerlendirmek amacıyla Ingilizce olarak geliştirilmiştir. Amerika Birleşik Devletleri ve birçok farklı ülkede yaygın olarak kullanılan bir ölçektir. 2009 yılında, Negriff ve ark. tarafından adölesanlar üzerinde faktör yapısı ve kullanılabilirliği tekrar değerlendirilerek güncelleştirilmiştir. Ölçeğin Türkçe'ye uyarlanması Güvenç ve arkadaşları tarafından 2014 yılında yapılmıştır. Katılımcılardan menstruasyonla ilgili yaşadıkları belirtilere 1 (hiç bir zaman) ve 5 (her zaman) arasında bir numara vermeleri istenmektedir. Ölçek maddeleri, kullanım kolaylığı olması için ayrılan faktörlere göre numaralandırılmıştır. 1-13. maddeler "Negatif etkiler/ somatik yakınmalar" alt boyutuna ait, 14-19. maddeler "Menstrual ağrı belirtileri" alt boyutuna ve 20-22. maddeler "Baş etme yöntemleri" alt boyutuna aittir. Cronbach's Alpha değeri 0.86 'dır. 22 maddeden oluşan beşli likert tipi bir ölçektir. Alt boyutlardan alınan puan, alt boyutlarda yer alan maddelerin toplam puan ortalaması alınarak hesaplanmaktadır. Alt boyutlar için puan ortalamasının yükselmesi, o alt boyuta ilişkin menstrual semptompların siddetinin arttığını göstermektedir (10). Bu araştırmada Cronbach's Alpha değeri 0.89 'dur.

\section{Yaşam kalitesi ölçeği (SF-12)}

"The Institute of Health" tarafından 1994 yılında geliştirilen SF-12 Yaşam Kalitesi Ölçeği (SF-12), belirli bir yaş grubuna ve hastalık grubuna odaklanmaksızın son dört hafta için yaşam kalitesini değerlendiren bir ölçektir. SF 12' nin tamamı SF-36 Yaşam Kalitesi Ölçeğinden seçilmiş olan 12 sorudan oluşmaktadır. SF-36 Türkçe versiyonunun güvenilirlik ve geçerlilik çalışması Koçyiğit ve arkadaşları tarafından yapılmıştır. SF-12'nin uygulamasının kolay ve tamamlanma süresinin daha kısa olması nedeni ile kullanımının SF-36'dan daha avantajlı olduğu bildirilmiştir $(22,23,24)$. SF-36'nın farklı 8 alt başlığından 12 farklı madde alınarak daha kısa bir form haline getirilen SF-12, Fiziksel Bileşenler Özet Skoru (FBÖS) ve Mental Bileşenler Özet Skoru (MBÖS) olmak üzere iki farklı boyuttan oluşmaktadır. SF-36'da puanlama hesaplanırken kullanılan T-skoru SF-12'de kullanılmamaktadır. Bunun yerine farklı bir skorlama kuralı kullanılmaktadır. Bireylerin verdikleri cevaplar için fiziksel standardizasyon değerleri ve mental standardizasyon değerleri ayrı ayrı toplanmaktadır. Son olarak, 12 soru için fiziksel standardizasyon toplamına 56,57706 eklenerek fiziksel bileşenlerin özeti, 12 soru için mental standardizasyon toplamına 60,75781 eklenerek mental bileşenlerin özeti hesaplanmaktadır. Yüksek skorlar iyi sağlık durumunu göstermektedir (24).

\section{Verilerin toplanması}

Veriler araştırmacılar tarafından hafta içi günlerde, öğrencilerin ders saatleri dışında toplanmıştır. Veri toplama formları sınıf ortamında, gerekli açıklamalar yapıldıktan sonra dağıtılmış ve öğrencilerin bireysel olarak soruları cevaplamaları istenmiştir.

\section{Verilerin değerlendirilmesi}

Verilerin kodlanması ve değerlendirilmesi SPSS 16.0 paket programı kullanılarak bilgisayar ortamında gerçekleştirilmiştir. İstatistiksel değerlendirmede; yüzdelik dağılım, aritmetik ortalama, standart sapma, cronbach alfa ve pearson korelasyon analizleri kullanılmıştır.

\section{Etik düzenlemeler}

Araştırmanın uygulanabilmesi için İnönü Üniversitesi Sağlık Bilimleri Bilimsel Araştırma ve Yayın Etiği Kurulu'ndan onay alınmıştır (Karar No: 2017/8-2). Ayrıca, İnönü Üniversitesi Rektörlüğünden yazılı izin alınmıştır. Araştırmaya başlamadan önce, öğrencilere araştırma hakkında bilgi verilerek, bireysel bilgilerinin korunacağı belirtilmiş ve gönüllü olanlar araştırmaya dahil edilmiştir.

\section{Bulgular}

Öğrencilerin tanıtıcı özelliklerinin dağılımı Tablo 1'de verilmiştir. Araştırmaya katılan öğrencilerin yaş ortalaması $20.82 \pm 1.67$ olup, ortalama menarş yaşı $13.50 \pm 1.55$ olarak saptanmıştır. Öğrencilerin \%30 unun birinci sınıf öğrencisi olduğu ve \%84.4'ünün orta düzeyde gelire sahip olduğu tespit edilmiştir. Öğrencilerin \%70.22sinin menstruasyonunun düzenli olduğu ve $\% 54.8^{\prime}$ inin ailesinde menstrual semptom yaşanmadığı saptanmıştır. 
Tablo 1. Öğrencilerin tanıtıcı özelliklerinin dağılımı $(n=1019)$

\begin{tabular}{|c|c|c|}
\hline Değişken & \multicolumn{2}{|c|}{$\bar{x} \pm S S$} \\
\hline Yaş & \multicolumn{2}{|c|}{$20.82 \pm 1.67$} \\
\hline \multirow[t]{2}{*}{ Menarş yaşı } & \multicolumn{2}{|c|}{$13.50 \pm 1.55$} \\
\hline & $n$ & $\%$ \\
\hline \multicolumn{3}{|l|}{ Fakülte } \\
\hline Fen bilimleri & 395 & 38.8 \\
\hline Sağlık bilimleri & 208 & 20.4 \\
\hline Sosyal bilimler & 224 & 22.0 \\
\hline Eğitim bilimleri & 192 & 18.8 \\
\hline \multicolumn{3}{|l|}{ Sinıf } \\
\hline Birinci sınıf & 306 & 30.0 \\
\hline İkinci sınıf & 296 & 29.0 \\
\hline Üçüncü sınıf & 252 & 24.7 \\
\hline Dördüncü sınıf & 165 & 16.2 \\
\hline \multicolumn{3}{|c|}{ Ekonomik durum } \\
\hline Düşük & 130 & 12.8 \\
\hline Orta & 860 & 84.4 \\
\hline Yüksek & 29 & 2.8 \\
\hline \multicolumn{3}{|l|}{ Aile tipi } \\
\hline Çekirdek & 809 & 79.4 \\
\hline Geleneksel & 184 & 18.1 \\
\hline Parçalanmış & 26 & 2.6 \\
\hline \multicolumn{3}{|c|}{ Menstruasyon Düzeni } \\
\hline Düzenli & 715 & 70.2 \\
\hline Düzensiz & 304 & 29.8 \\
\hline \multicolumn{3}{|c|}{ Ailede Menstrual Semptom Varlığı } \\
\hline Evet & 461 & 45.2 \\
\hline Hayır & 558 & 54.8 \\
\hline Toplam & 1019 & 100 \\
\hline
\end{tabular}

Öğrencilerin menstruasyon semptom ölçeği toplam ve alt boyutlarından aldıkları puan ortalamaları ile SF-12 yaşam kalitesi ölçeği alt boyutlarından aldıkları puan ortalamalarının dağılımı Tablo 2'de verilmiştir. MSÖ negatif etkiler/somatik yakınmalardan elde edilen puan ortalamasının 40.45 \pm 10.63 olduğu, menstrual ağrı belirtilerinin puan ortalamasının $21.22 \pm 6.07$ olduğu ve baş etme yöntemlerinden alınan puan ortalamasının $7.67 \pm 4.08$ olduğu saptanmıştır. Öğrencilerin, fiziksel bileşenler özet skoru puan ortalamasının $46.01 \pm 8.35$ olduğu ve mental bileşenler özet skoru puan ortalamasının $36.41 \pm 7.72$ olduğu belirlenmiştir.

SF-12 fiziksel bileşenler özet skoru (FBÖS) ve mental bileşenler özet skoru (MBÖS) ile menstruasyon semptom ölçeği puan ortalamaları arasındaki ilişki Tablo 3'de verilmiştir.
Tablo 2. Öğrencilerin menstruasyon semptom ölçeği toplam ve alt boyutlarından aldıkları puan ortalamaları ile SF-12 yaşam kalitesi ölçeği alt boyutlarından aldıkları puan ortalamalarının dağıımı $(n=1019)$

\begin{tabular}{lc} 
Ölçek & $\overline{\boldsymbol{x}} \pm \boldsymbol{S D}$ \\
\hline MSÖ & \\
Negatif Etkiler/Somatik Yakınmalar & $40.45 \pm 10.63$ \\
Menstrual Ağrı Belirtileri & $21.22 \pm 6.07$ \\
Baş Etme Yöntemleri & $7.67 \pm 4.08$ \\
MSÖ Toplam & $69.36 \pm 17.59$ \\
SF- 12 & \\
Fiziksel Bileşenler Özet Skoru (FBÖS) & $46.01 \pm 8.35$ \\
Mental Bileşenler Özet Skoru (MBÖS) & $36.41 \pm 7.72$
\end{tabular}

Tablo 3. SF-12 fiziksel bileşenler özet skoru (FBÖS) ve SF-12 mental bileşenler özet skoru (MBÖS) ile menstruasyon semptom ölçeği puan ortalamaları arasındaki ilişki $(n=1019)$

\begin{tabular}{lccc} 
MSÖ & RB & FBÖS & MBÖS \\
\hline Negatif Etkiler/Somatik Yakınmalar & $r$ & -0.258 & -0.136 \\
& $p$ & $\mathbf{0 . 0 0 0 *}$ & $\mathbf{0 . 0 0 0 *}$ \\
Menstrual Ağrı Belirtileri & $r$ & -0.206 & -0.117 \\
& $p$ & $\mathbf{0 . 0 0 0 *}$ & $\mathbf{0 . 0 0 0 *}$ \\
Baş Etme Yöntemleri & $r$ & -0.181 & -0.116 \\
& $p$ & $\mathbf{0 . 0 0 0 *}$ & $\mathbf{0 . 0 0 0 *}$ \\
Toplam & $r$ & -0.270 & -0.150 \\
& $p$ & $\mathbf{0 . 0 0 0 *}$ & $\mathbf{0 . 0 0 0 *}$ \\
\hline$\beta$ Pearson Korelasyon & $p$ & & \\
${ }^{*} p<0.001$ & & &
\end{tabular}

SF-12 FBÖS ile MSÖ "Negatif Etkiler/Somatik Yakınmalar", "Menstrual Ağrı Belirtileri" ve "Baş Etme Yöntemleri" alt boyutları ile "MSÖ toplam" puan ortalamaları arasında negatif yönde zayıf düzeyde anlamlı bir ilişki olduğu belirlenmiştir ( $p$ <.001). Öğrencilerde menstrual semptom şiddeti arttıkça, fiziksel yaşam kalitesinin azaldığı görülmektedir.

SF-12 MBÖS ile MSÖ "Negatif Etkiler/Somatik Yakınmalar", "Menstrual Ağrı Belirtileri" ve "Baş Etme Yöntemleri" alt boyutları ile "MSÖ toplam" puan ortalamaları arasında negatif yönde çok zayıf düzeyde anlamlı bir ilişki olduğu saptanmıştır $(p<0.001)$. Öğrencilerde menstrual semptom şiddeti arttıkça, mental yaşam kalitesinin azaldığı görülmektedir.

\section{Tartışma}

Araştırmada 1019 üniversite öğrencisinin menstrual semptom yaşama durumu ve yaşam kalitesine etkisi değerlendirilmiştir. Yaş ortalamaları $20.82 \pm 1.67$ ve menarş 
yaş ortalamaları $13.50 \pm 1.55$ olan öğrencilerin menstrual özellikleri değerlendirildiğinde, \%70.2'sinin menstrual periyodlarının düzenli olduğu belirlenmiştir. Öğrenciler üzerinde yapılan araştırmalarda Nooh, öğrencilerin \%73.1' inin, Aşçı ve arkadaşları \%88.5'inin menstrual siklusunun düzenli olduğunu saptamıştır $(25,26)$. Türkiye Kadın Sağlığı Araştırması sonuçlarında benzer şekilde kadınların \%84.11'inin menstrual periyodlarının düzenli olduğu görülmektedir (27). Araştırma bulguları literatüre benzer şekilde öğrencilerde menstrual peiyodların büyük oranda düzenli olduğunu göstermektedir.

Araştırmada, SF-12 FBÖS ve MBÖS alt boyutları ile MSÖ toplam puan ortalamaları arasında negatif yönde zayıf düzeyde anlamlı bir ilişki olduğu ve öğrencilerde menstrual semptom şiddeti arttıkça fiziksel ve mental yaşam kalitesinin azaldığı görülmektedir (Tablo 3, p=0.001). Araştırma bulgularına göre, öğrencilerin menstrual semptom yaşamaları yaşam kalitelerini hem fiziksel hem de mental açıdan olumsuz etkilemektedir. Bu bulgu menstrual semptomların yaşam kalitesi üzerinde önemli bir etken olduğu şeklinde yorumlanabilir. Literatürde benzer şekilde, kadınlarda ve özellikle genç kızlarda menstrual semptomlara bağlı yaşam kalitesinin olumsuz etkilendiği belirtilmektedir $(2,5,8,9,18,25,28)$. Ayrıca, üreme çağındaki kadınların \%70-90'ının menstrual yakınmaları deneyimlediği, \%20-40'ında bu yakınmaların yaşam kalitelerini etkileyecek düzeyde, \%5-10'unda ise çok şiddetli bir biçimde yaşanmakta olduğu bildirilmektedir (29).

Araştırmada öğrencilerin MSÖ negatif etkiler/somatik yakınmalar alt boyutundan elde edilen puan ortalamasının $40.45 \pm 10.63$ ile en yaygın menstrual yakınma olarak belirtildiği ve negatif etkiler/somatik yakınmalar arttıkça fiziksel ve mental yaşam kalitesinin anlamlı düzeyde azaldığı saptanmıştır (Tablo 3, p=0.001). Araştırmada, öğrencilerin negatif etkiler hissetmesi (sinirlilik, gerginlik, öfke vb.) ve somatik/bedensel şikayetlerinin artması (güçsüzlük, halsizlik, yorgunluk vb.) ile hem fiziksel hem de mental yaşam kalitelerinin olumsuz etkilediğini görülmektedir. Öğrencilerin menstruasyon semptomlarına bağlı yaşam kalitelerinin fiziksel ve mental açıdan etkilenmesini değerlendiren literatür bilgisi incelendiğinde, menstruasyon sırasında kolay öfkelenme, gerginlik, anksiyete ve ruh halinde değişikliklerin sık rastlanılan psikolojik şikayetler olduğu bildirilmektedir $(1,3,4,30)$. Wong ve Khoo yaptıkları araştırmada, premenstrual dönemdeki öğrencilerin \%80.7'sinin bir, \%83.6'sının ise daha fazla duygusal ve somatik yakınma yaşadığını saptamıştır (19). Eğicioğlu ve arkadaşları öfkeli ruh hali ve yorgunluğun bedensel ağrı, canlılık ve mental sağlık puanlarını anlamlı olarak azaltarak yaşam kalitesini düşürdüğünü saptamışlardır (31). Bu bağlamda elde edilen bulgunun literatürle uyumlu olduğu ve negatif etkiler ve somatik yakınmalar yaşayan öğrencilerin fiziksel ve mental yaşam kalitelerinin daha düşük olduğu görülmektedir.

Araştırmada öğrencilerin MSÖ menstrual ağrı belirtileri alt boyutundan elde edilen puan ortalamalarının $21.22 \pm 6.07$ olduğu ve menstrual ağrı belirtileri arttıkça fiziksel ve mental yaşam kalitesinin anlamlı düzeyde azaldığı belirlenmiştir (Tablo 3, p=0.001). Literatür incelendiğinde menstrual ağrısının kadın ve genç kızların günlük yaşamlarını, iş ve okul hayatlarını olumsuz etkilediği görülmektedir $(21,26)$. Bu olumsuz etkinin fiziksel ve mental yaşam kalitesinde azalmaya neden olduğu düşünülmektedir. Yılmaz ve Başer üniversite öğrencileri üzerinde yaptıkları araştırmada, dismenore nedeniyle öğrencilerin \%41.7'sinin okula gidemediğini ve \%51.6'sının ise ders çalışamadığını saptamıştır (21). Aşçı ve arkadaşları üniversite öğrencileri üzerinde yaptıkları araştırmada öğrencilerin \%70.7' sinin premenstrual dönemde ağrı, \%67.7'sinin ise menstrual dönemde günlük aktivitelerini engelleyecek derecede ağrı yaşadıklarını belirlemiştir (26). Benzer şekilde Karout, üniversite öğrencileri üzerinde yaptığı araştırmada öğrencilerin \%96.3'ünün menstrual dönemde dismenore yaşadığı, özellikle \%35.8'inin ise dismenoreden ciddi derecede yakındığını saptamıştır (28). Bu açıdan değerlendirildiğinde elde edilen bulgunun literatürle uyumlu olduğu ve menstrual ağrı belirtileri arttıkça yaşam kalitesinin azaldığı görülmektedir.

Araştırmada öğrencilerin menstrual semptomlarla baş etme mekanizmalarına bakıldığında, öğrencilerin MSÖ baş etme yöntemleri puan ortalamaları arttıkça fiziksel ve mental yaşam kalitelerinin anlamlı düzeyde azaldığı saptanmıştır (Tablo 3, p=0.001). MSÖ baş etme yöntemleri alt boyutunda sorgulanan ağrı kesici ve sıcak uygulama gibi başetme yöntemlerinin kullanımı arttıkça (10) öğrencilerdeki fiziksel ve mental yaşam kalitesinin düştüğü görülmektedir. Bu bulgu artan menstrual semptom şiddetinin öğrencilerdeki yaşam kalitesini düşürdüğü ve öğrencilerin yaşam kalitesini yükseltmek için daha fazla başetme yöntemlerine başvurduğu şeklinde yorumlanabilir. Şanlı ve Oskay yaptıkları araştırmada öğrencilerin \%78.1'i mensturasyon döneminin okul aktivitelerini etkilediğini ve bu nedenle \%34.7'sinin doktora başvurduklarını belirtmişlerdir (32). Literatürde de benzer şekilde menstrual semptom şiddeti artıkça, günlük aktiviteleri yerine getirememe, hekime başvurma ve ilaç kullanma gibi eylemlerin arttığı belirtilmiştir (33). Elde edilen bulgu literatürle uyumludur. Araştırma, bir kamu üniversitesinde öğrenim gören kız öğrenciler ile sınırlıdır. 


\section{Sonuç ve öneriler}

Öğrencilerde negatif etkiler/somatik yakınmalar, menstrual ağrı şikayetleri ve mensturual semptomlarla başetme yöntemlerine başvurunun yaygın olduğu ve menstrual semptom şiddeti arttıkça yaşam kalitesinin azaldığı

\section{Kaynaklar}

1. Erbil N, Bölükbaş N, Tolan S, Uysal F. Evli Kadınlarda Premenstrual Sendrom Görülme Durumu ve Etkileyen Faktörlerin Belirlenmesi. Uluslararası İnsan Bilimler Dergisi 2011;8:427-37.

2. Arı̈z A, Ege E. Premenstrüel Sendrom Sorunu Olan Üniversite Öğrencilerinde, Semptomların Kontrolü ve Yaşam Kalitesinin Artırılmasında Eğitimin Etkinliği. Genel Tıp Derg 2013;23:63-9.

3. Balık G, Hocaoğlu Ç, Kağıtcı M, Güvenda GES. Comparison of The Effects of PMDD and Premenstrual Syndrome on Mood Disorders and Quality of Life. J Obstet Gynaecol 2015;35:616-20. [CrossRef]

4. Oskay Ü, Can G, Taş D, Sezgin Ö. Hemşirelik Yüksekokulu Öğrencilerinde Görülen Perimenstrual Sorunlar. I.Ü.F.N. Hem. Derg 2008;16:157-64.

5. Kısa S, Zeyneloğlu S, Güler N. Üniversite Öğrencilerinde Premenstrual Sendrom Görülme Sıklığı ve Etkileyen Faktörler. Gümüşhane Üniversitesi Sağlık Bilimleri Dergisi 2012;1:284 -97.

6. Selçuk KT, Avcı D, Yılmaz FA. Hemşirelik Öğrencilerinde Premenstrual Sendrom Prevalansı ve Etkileyen Etmenler. Psikiyatri Hemşireliği Dergisi 2014;5:98-103. [CrossRef]

7. Padmavathi P. Effect of Acupressure Vs Reflexology on Pre-Menstrual Syndrome Among Adolescent Girls. Nurs J India 2014;105:236-9.

8. Moghadam, ZB, Rezaei E, Gholami RS, Kheirkhah M, Haghani H.The Effect of Valerian Root Extract on The Severity of PreMenstrual Syndrome Symptoms. J Tradit Complement Med 2016;6:309-15. [CrossRef]

9. Kırcan N, Ergin F, Adana F, Arslantaş H. Hemşirelik Öğrencilerinde Premenstrual Sendrom Prevalansı ve Yaşam Kalitesi İle İlişkisi. ADÜ Tıp Fakültesi Dergisi 2012;13:19-25.

10. Güvenç G, Seven M, Akyüz A. Menstrüasyon Semptom Ölçeği'nin Türkçe'ye Uyarlanması. TAF Prev Med Bull 2014,13:367-74. [CrossRef]

11. Gümüş $A B$, Bayram N, Can N, Kader E. Üniversite Öğrencilerinde Premenstruel Sendrom ve Somatizasyon. Anadolu Psikiyatri Derg 2012,13:32-8.

12. Samadi Z, Taghian F, Valiani M. The Effects of 8 Weeks of Regular Aerobic Exercise on The Symptoms of Premenstrual Syndrome in Non-Athlete Girls. Iran J Nurs Midwifery Res 2013;18:14-9.

13. Rode MV, Kamble P, Phatak MS. Jadhao P, Tayde P. Effect of Premenstrual Stress on Autonomic Function. Annals of Neurosciences 2010;17:131-3. [CrossRef]

14. Qiao M, Zhang H, Liu H, Luo S, Wang T, Zhang J, Ji L. Prevalence of premenstrual syndrome and premenstrual dysphoric disorder in a population-based sample in China. Eur J Obstet Gynecol Reprod Biol 2012;162: 83-6. [CrossRef]

15. Çepni İ. i.Ü. Dismenore. Cerrahpaşa Tıp Fakültesi Sürekli Tıp Eğitimi Etkinlikleri Adolesan Sağlığı Sempozyum Dizisi 43, 2005;151-7.

16. Patel V, Tanksale V, Sahasrabhojanee M, Gupte S, Nevrekar P. The Burden and Determinants of Dysmenorrhoea: A Population-Based Survey of 2262 Women in Goa. BJOG 2006;113:453-63. [CrossRef]

17. Uran P, Yürümez E, Aysev A, Kılıç BG. Premenstrual Syndrome HealthRelated Quality of Life and Psychiatric Comorbidity in a Clinical Adolescent Sample: A Cross-Sectional Study. Int J Psychiatry Clin Pract 2017;21:36-40. [CrossRef] belirlenmiştir. Menstrual dönem ve semptomları hakkında yazılı-görsel materyaller aracılığı ile etkin danışmanlık hizmetlerinin sağlanması ve uygun başetme yöntemlerinin geliştirilmesi, menstrual semptomlara bağlı yaşam kalitesinin yükseltilmesine katkı sağlayacaktır.

18. Öztürk S, Tanrıverdi D. Premenstrual Sendrom ve Başetme. Anadolu Hemşirelik ve Sağlık Bilimleri Dergisi 2010;13:57-61.

19. Wong LP, Khoo EM. Menstrual-Related Attitudes and Symptoms Among Multi-racial Asian Adolescent Females. Int. J. Behav. Med 2011;18:246-53. [CrossRef]

20. Tolossa FW, Bekele ML. Prevalence, Impacts and Medical Managements of Premenstrual Syndrome Among Female Studets: Cross-sectional Study in Collage of Health Sciences, Mekele University, Mekele, Northern Ethiopia. BMC Women's Health 2014;14:52. [CrossRef]

21. Yılmaz FA, Başer M. Dismenorenin Okul Performansına Etkisi. GUSBD 2016;5:29-33

22. Kaynak C. İnönü Emin Aytan Sağlık Ocağı Bölgesinde Yoksulluğun Sağlık Üzerine Etkisi. Halk Sağlığı Anabilim Dalı Uzmanlık Tezi: Dokuz Eylül Üniversitesi 2006; s:23.

23. Sönmez Y, Uçku R, Kıtay Ş, Korkut H, Sürücü S, Sezer M ve ark. İzmir'de Bir Sağlık Ocağı Bölgesinde Yaşayan 75 Yaş ve Üzeri Bireylerde Yaşam Kalitesi ve Etkileyen Etmenler. DEÜ Tıp Fakültesi Dergisi 2007; 21:145-53.

24. Korur AP. Adana III Merkezinde Yaşayan Farklı Sosyokültürel Grupların Sağlık Hizmetlerini Kullanma Davranışlarının Değerlendirilmesi. Aile Hekimliği Anabilim Dalı Uzmanlık Tezi Adana: Çukurova Üniversitesi 2010; s:18.

25. Nooh AM. Menstrual Disorders Among Zagazig University Students, Zagazig, Egypt. Middle East Fertility Society Journal 2015;20:198203. [CrossRef]

26. Aşcı Ö, Gökdemir F, Özcan B. Genç Kızların Premenstrüel ve Menstrüel Yakınmalarla Baş Etme Yollarının Belirlenmesi. Uluslararası Hakemli Kadın Hastalıkları ve Anne Çocuk Sağlığı Dergisi 2015;3:1634. [CrossRef]

27. T.C. Sağlık Bakanlığı Sağlık Araştırmaları Genel Müdürlüğü. Türkiye Kadın Sağlığı Araştırması. T.C. Sağlık Bakanlığı Yayın No: 943, 2014;s:39.

28. Karout N. Prevalence And Pattern of Menstrual Problems And Relationship with Some Factors Among Saudi Nursing Students. Journal of Nursing Education and Practice 2015;5:1-8. [CrossRef]

29. Daşıkan Z, Saruhan A. Çalışan Hemşirelerde Menstrüel Yakınmaların İncelenmesi. Sted 2014;23: 1-7.

30. Işık H, Ergöl Ş, Aynıoğlu Ö, Şahbaz A, Kuzu A, Uzun M. Premenstrual Syndrome and Life Quality in Turkish Health Science Students. Turk J Med Sci 2016;46: 695-701. [CrossRef]

31. Eğicioğlu H, Coşar E, Kundak Z, Pektaş M, Köken G. Premenstrüel Sendromun Yaşam Kalitesine Olan Etkileri, Sosyodemografik Özelliklerle İlişkili mi? Jinekoloji - Obstetrik ve Neonatoloji Tıp Dergisi 2015;12:10-17.

32. Şanlı Y, Oskay Ü. Üniversite Sınavına Hazırlanan Kız Öğrencilerin Sınav Kaygıları Ile Adet Sorunları Arasındaki Illişki. International Journal of Human Sciences 2015; 12:719-31. [CrossRef]

33. Taşçı KD. Hemşirelik Öğrencilerinin Premenstural Semptomlarının Değerlendirilmesi. TAF Preventive Medicine Bulletin 2006;5:434-43. 